\title{
Kualitas Fisik Telur Ayam Petelur pada Tingkat Pelaku Usaha di Kabupaten Manokwari Provinsi Papua Barat
}

\section{Physical Quality of Layer Eggs Supply at the Level of Local Business in Manokwari Regency West Papua Province}

\author{
Ahmad Kamaruddin ${ }^{1,2)}$, Hanike Monim ${ }^{3)}$, Mulyadi ${ }^{3)}$, Priyo Sambodo ${ }^{3 *}$ \\ ${ }^{1)}$ Pascasarjana Ilmu Peternakan, Program Pascasarjana, Universitas Papua, Manokwari \\ Jl. Gunung Salju, Amban, Manokwari 98314, Papua Barat. Indonesia \\ ${ }^{2)}$ Dinas Peternakan dan Kesehatan Hewan, Provinsi Papua Barat \\ Anday, Manokwari Selatan, Manokwari 98315, Papua Barat. Indonesia \\ ${ }^{3)}$ Laboratorium Produksi Ternak, Fakultas Peternakan, Universitas Papua, Manokwari \\ Jl. Gunung Salju, Amban, Manokwari 98314, Papua Barat. Indonesia
}

\section{Article history \\ Received: May 21, 2020; \\ Accepted: Sep 26, 2020 \\ * Corresponding author: \\ E-mail: \\ drh_priyo01@yahoo.com \\ DOI: \\ 10.46549/jipvet.v10i2.111}

\begin{abstract}
The goal of this study is to determine the physical qualities of chicken egg supply at the level of local business in Manokwari Regency West Papua Province. Egg samples were taken from three distributors with a storage period of 12 days and two retailer market groups namely the traditional market and modern market for 17 days and 22 days respectively. The physical qualities measured were the air sac height, albumin index, and the egg storage period of 12 days, 17 days, and 22 days. The results showed that the quality of the chicken egg supply in the Manokwari Regency had lowered physical qualities.
\end{abstract}

Keywords: Chicken eggs; Physical quality; Storage time; Businessman

\begin{abstract}
Abstrak
Penelitian ini bertujuan untuk mengetahui kualitas fisik, lama penyimpanan dan rantai pemasaran telur ayam ras pasok pada distributor dan pengecer di Kabupaten Manokwari Provinsi Papua Barat. Sampel telur diperoleh dari tiga distributor dengan lama penyimpanan 12 hari dari pengecer yaitu pasar tradisional dan pasar moderen untuk masing-masing lama penyimpanan 17 hari dan 22 hari. Kualitas fisik yang diukur adalah kedalaman kantong udara, indeks albumin dan indeks yolk serta lama penyimpanan telur yang meliputi 12 hari, 17 hari dan 22 hari. Hasil penelitian menunjukkan bahwa telur ayam ras pasok yang beredar di Kabupaten Manokwari telah mengalami penurunan kualitas fisik.
\end{abstract}

Kata kunci: Telur ayam; Kualitas fisik; Lama penyimpanan; Pelaku usaha

\section{PENDAHULUAN}

Telur adalah salah satu bahan makanan asal ternak yang dikenal bernilai gizi tinggi karena mengandung zat-zat makanan yang sangat dibutuhkan oleh tubuh manusia, seperti asamasam amino yang lengkap dan seimbang, vitamin serta mempunyai daya cerna yang tinggi (Idris, 1994). Kabupaten Manokwari sebagai Ibu Kota Provinsi Papua Barat dengan total jumlah penduduk sebanyak 937.458 jiwa (BPS, 2018) memiliki tingkat kebutuhan terhadap ketersediaan telur ayam konsumsi cukup tinggi, yaitu mencapai $1.650 .874 \mathrm{~kg}$ (Stasiun Karantina Pertanian Kelas II Manokwari, 2016).

Seiring dengan semakin berkembangnya pembangunan daerah di Kabupaten Manokwari, kualitas hidup masyarakatpun meningkat. Hal ini menyebabkan tuntutan 
masyarakat akan jaminan kualitas keamanan bahan pangan, termasuk bahan pangan asal telur ayam ras, meningkat bersamaan dengan jumlah yang akan dikonsumsi. Hal tersebut menyebabkan tingkat permintaan telur ayam ras dari luar daerah sangat tinggi bahkan dua kali lipat melebihi ketersediaan telur ayam ras lokal di Kabupaten Manokwari yang hanya mencapai $928.314 \mathrm{~kg}$ (Dinas Peternakan dan Kesehatan Hewan Provinsi Papua Barat, 2016).

Transportasi laut yang membutuhkan waktu selama 7 hari perjalanan tanpa perlakuan khusus untuk menjamin kualitas telur yang dibawa ke Manokwari merupakan salah satu titik kritis yang perlu diantisipasi dalam upaya mengurangi resiko keamanan pangan. Waktu transportasi dapat dikategorikan sebagai lama penyimpanan yang akan mempengaruhi kualitas telur selain penyakit, induk, pakan, kelembaban dan suhu penyimpanan.

Berdasarkan uraian di atas, maka perlu dilakukan pengujian kualitas fisik telur ayam ras pasok yang beredar di Kabupaten Manokwari sebelum tiba ditangan konsumen. Penelitian ini bertujuan untuk mengetahui kualitas fisik, lama penyimpanan dan rantai pemasaran telur ayam ras pasok pada distributor dan pengecer di Kabupaten Manokwari Provinsi Papua Barat.

\section{MATERI DAN METODE}

Penelitian ini dilaksanakan di Laboratorium Teknologi Hasil Ternak Fakultas Peternakan Universitas Papua Manokwari. Penentuan lokasi pengambilan sampel pada distributor dilakukan secara purposif berdasarkan total jumlah pemasukan telur ayam ras tiga terbesar. Penentuan pengecer berdasarkan tempat penjualan, yaitu pada pasar tradisional dan pada pasar moderen. Sampel pada pengecer ditentukan secara purposif berdasarkan jumlah total telur tertinggi yang dijual setiap pengecer. Penentuan pengumpulan sampel pada tingkat distributor yaitu pada hari pertama telur tiba di Manokwari dan tingkat pengecer dilakukan pada hari kedua dan ketiga. Sampel kontrol diambil dari tiga peternak ayam ras petelur lokal yang ada di Kabupaten Manokwari. Sebanyak 84 butir telur dari distributor dan 252 butir telur dari pengecer digunakan dalam penelitian ini.
Penelitian ini dilakukan dengan menggunakan metode deskriptif dengan teknik studi kasus. Kualitas fisik telur sampel meliputi: kedalaman kantong udara, indeks albumin dan indeks yolk. Sedangkan studi kasus yang diamati yaitu lama penyimpanan telur yang meliputi 12 hari (T0), 17 hari (T1) dan 22 hari (T2) berdasarkan petunjuk distributor dan pengecer.

\section{ANALISIS DATA}

Data yang diperoleh dianalisis dengan cara tabulasi dan data tabulasi yang diperoleh selanjutnya dilakukan perbandingan dengan persyaratan Telur Ayam Konsumsi (SNI 3926, 2008).

\section{HASIL DAN PEMBAHASAN}

\section{KARAKTERISTIK PASAR}

Pada umumnya sebagian infrastruktur pasar di Kabupaten Manokwari sudah tersedia namun masih dalam tahap pembangunan ataupun renovasi. Aktifitas kegiatan jual-beli, khususnya bahan pangan umumnya dilakukan setiap hari, walaupun penjualannya ada yang tidak dilakukan pada tempat yang disediakan (pasar tradisional).

Produk telur umumnya bercampur dengan produk kelontongan lainnya dan pada umumnya mempunyai kesan yang kurang higienis. Hal ini dapat dilihat dari kondisi lantai yang belum semua tertutup oleh semen, sehingga pada saat hujan banyak dijumpai kubangan-kubangan air dan pada saat kering berdebu. Adapun suhu udara pada pasar tradisional, baik di Pasar Wosi, Pasar Sanggeng, dan Pasar Prafi yaitu $27{ }^{\circ} \mathrm{C}-28{ }^{\circ} \mathrm{C}$ dengan kelembaban antara $80 \%-85 \%$. Keberadaan fisik pasar tradisional di Kabupaten Manokwari dapat dilihat pada Gambar 1a1-3.

Pasar moderen mempunyai kondisi lingkungan lebih bersih dan higienis serta dikelola oleh pihak yang profesional. Produk telur diletakkan ditempat khusus disekitar buah dan sayuran. Selain itu kondisi temperatur ruangan telah diatur sedemikian rupa yaitu dengan tersedianya Air Conditioner (AC) sehingga membuat suasana nyaman dan sejuk, dimana suhu udara berkisar $25{ }^{\circ} \mathrm{C}-27{ }^{\circ} \mathrm{C}$ dengan kelembaban antara 67\% - 69\%. 
Keberadaan fisik pasar moderen di Kabupaten Manokwari dapat dilihat pada Gambar 1b1-3.

Telur sejenis yang disimpan di lokasi higienis dan terpisah jelas akan memiliki kualitas yang lebih baik dibandingkan dengan telur yang disimpan di tempat yang kurang higienis dan bercampur dengan produk lain. Hal ini dipengaruhi oleh perbedaan jumlah mikoba yang dapat mempengaruhi produk telur tersebut. Selain itu, suhu penyimpanan juga sangat mempengaruhi kualitas (kulit) telur. Semakin meningkat suhu penyimpanan, maka permukaan kulit telur akan mengalami perubahan (Mountney, 1981) atau dengan kata lain kualitasnya menurun.
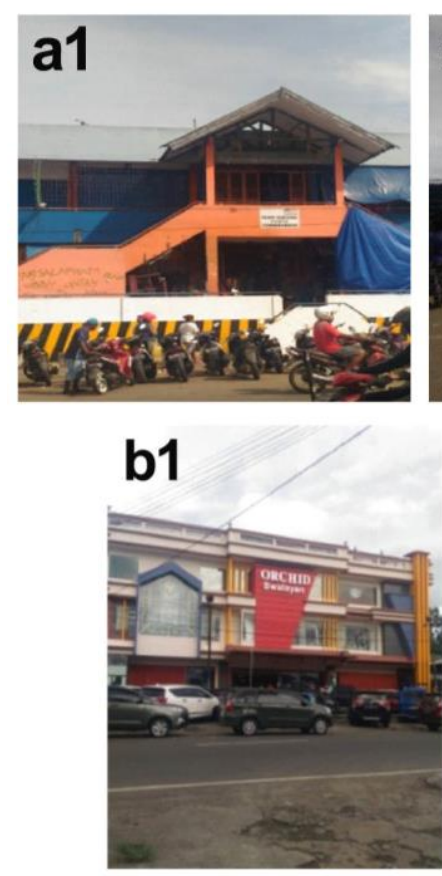
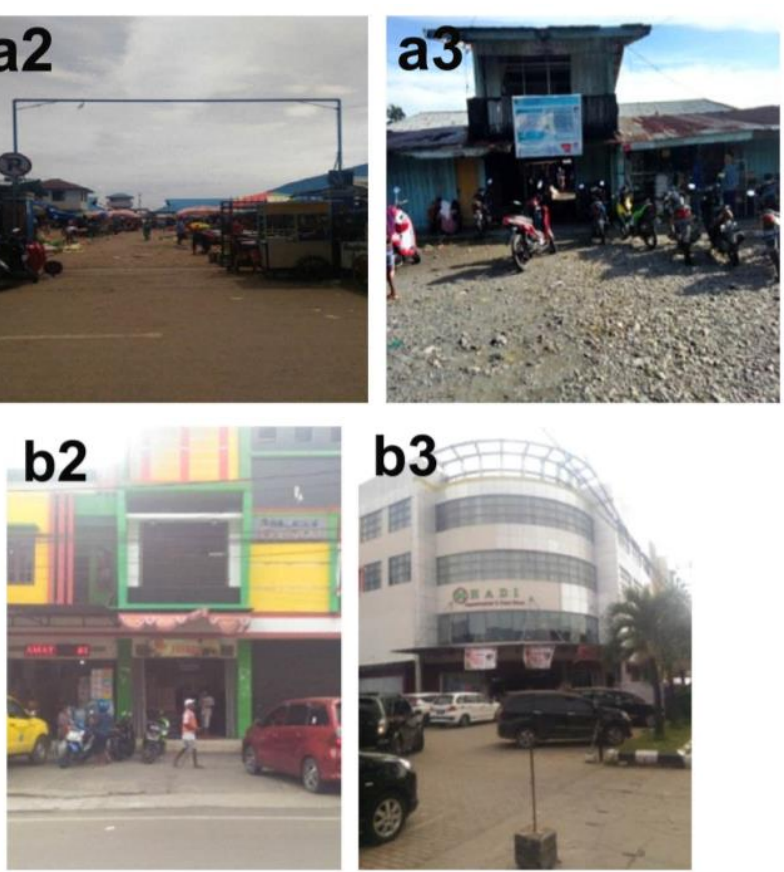

Gambar 1. Keadaan fisik pasar di Kabupaten Manokwari. (a1-3) pasar tradisional, (b1-3) pasar moderen

\section{KUALITAS FISIK TELUR \\ TINGKAT DISTRIBUTOR}

Berdasarkan SNI (3926:2008), kedalaman kantong udara, indeks albumin dan indeks yolk telur pasok pada tingkat distributor dengan lama penyimpanan T0 berada pada kategori tingkatan mutu II (kedalaman kantong udara: 0,5-0,9 cm; indeks albumin: 0,092-0,133; indeks york: 0,394-0,457). Sedangkan pada telur kontrol berada pada kategori tingkatan mutu I (kedalaman kantong udara: $<0,5 \mathrm{~cm}$; indeks albumin: 0,134-0,175; indeks york: 0,458-0,521) (Tabel 1).

\section{TINGKAT PENGECER}

Telur pasok memiliki kedalaman kantong udara cenderung lebih rendah dari telur lokal pada umur yang sama dan relatif sama dengan telur lokal masing-masing pada umur 19 hari, 24 hari dan 30 hari (Gambar 2A). Indeks albumin telur pasok pada $\mathrm{T} 2$ cenderung lebih rendah dari telur lokal pada umur yang sama, namun pada $\mathrm{T} 1$ relatif sama dengan kondisi indeks yolk telur lokal umur 30 hari (Gambar 2B). Indeks yolk telur pasok pada T1 cenderung lebih rendah dari telur lokal pada umur yang sama, namun pada T2 relatif sama dengan kondisi indeks yolk telur lokal umur 30 hari (Gambar 2C).

Berdasarkan uji kualitas fisik, telur pasok (di tingkat distributor dan pengecer) dan telur kontrol, telah mengalami penurunan kualitas seiring dengan lama penyimpanan T0, T1 dan T2. Kedalaman kantong udara telur ayam ras pasok relatif tinggi dibandingkan telur ayam ras lokal. Perbedaan ini diduga disebabkan oleh perbedaan suhu penyimpanan, dimana telur pasok selama transportasi laut disimpan dalam kontainer dengan suhu antara 38-39 ${ }^{\circ} \mathrm{C}$. Sedangkan telur lokal disimpan pada suhu kamar $\left(25-28{ }^{\circ} \mathrm{C}\right)$. Selain itu juga diduga disebabkan oleh umur penyimpanan telur pasok yang lebih lama (lebih dari 12 hari). Kontainer 
yang membawa telur yang tiba di pelabuhan Manokwari seringkali tidak segera 'dibongkar' karena mekanisme antri.

Kedalaman kantong telur pasok yang cederung tinggi di pasar tradisional II, diduga disebabkan oleh suhu yang cenderung lebih tinggi $\left(34,3-36,3{ }^{\circ} \mathrm{C}\right)$ dibanding pasar tradisional I $\left(29-30,9{ }^{\circ} \mathrm{C}\right)$ dan III $\left(28-30{ }^{\circ} \mathrm{C}\right)$ karena kurangnya sirkulasi udara sebagai akibat kondisi lapak pengecer yang dikelilingi oleh bangunan lapak lainnya. Hal ini sesuai dengan penelitian Samli et al. (2005) yang menunjukkan, bahwa semakin lama penyimpanan akan menyebabkan ukuran kantong udara semakin bertambah besar. Demikian juga hasil penelitian Kasmiati
(2014), dimana telur ayam ras yang beredar di kios, supermarket, pasar dan agen memiliki rongga udara yang bervariasi dengan kualitas $\mathrm{A}$ dan B, sedangkan kantong udara yang paling bagus terdapat pada telur yang berasal dari peternak lokal dimana sampel yang diambil berasal dari telur yang berumur satu hari sehingga memiliki kantong udara kecil. Ditambahkan oleh Arizona dan Ollong (2020), bahwa semakin lama penyimpanan, maka berdampak pada kualitas telur yang semakin menurun. Penurunan kualitas meliputi bobot telur, kekentalan albumin dan kuning telur serta besarnya rongga udara.

Tabel 1. Rata-rata kualitas fisik telur di tingkat distributor

\begin{tabular}{ccccc}
\hline $\begin{array}{c}\text { Lama } \\
\text { Simpan }\end{array}$ & Kelompok & $\begin{array}{c}\text { Kedalaman Kantong } \\
\text { Udara }(\mathbf{c m})\end{array}$ & Indeks Albumin & Indeks York \\
\hline \multirow{3}{*}{ T0 } & Kontrol & 0,433 & 0,173 & 0,517 \\
& D1 & 0,635 & 0,133 & 0,456 \\
& D2 & 0,711 & 0,132 & 0,452 \\
\hline
\end{tabular}

Keterangan= D: distributor
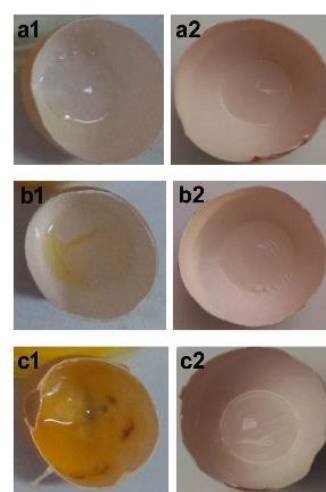

A
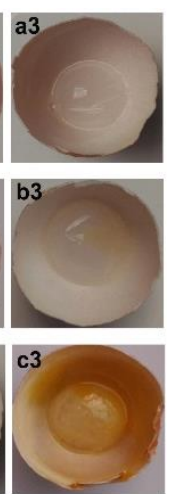
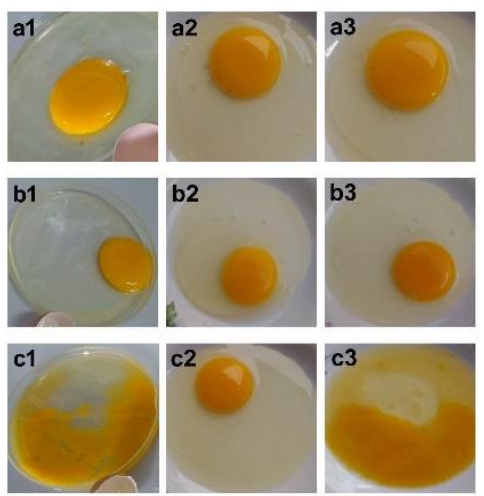

B

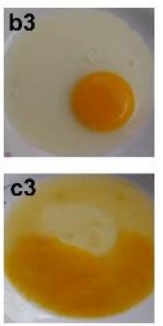

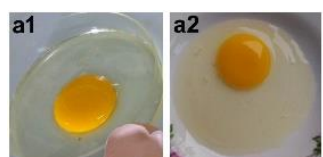
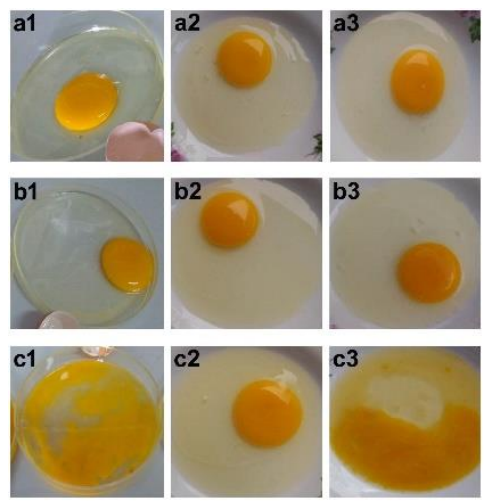

$\mathrm{C}$

Gambar 2. Perbandingan kondisi (A) kedalaman kantong udara, (B) indeks albumin, (C) indeks yolk telur pasok dan telur lokal pada: T0: (a1) telur pasok di distributor, (a2) telur lokal hari ke-12, (a3) telur lokal hari ke-19; T1: (b1) telur pasok pada pengecer, (b2) telur lokal hari ke-17, (b3) telur lokal hari ke-24; T2: (c1) telur pasok pada pengecer, (c2) telur lokal hari ke-22, (c3) telur lokal hari ke-30.

Salah satu perubahan yang terjadi pada saat penyimpanan telur utuh adalah pertambahan ukuran kantong udara, saat air hilang maka volume ruang udara akan bertambah (Carter, 1968 dalam Buckle, et al., 2009). Terjadinya ruang udara atau pemisahan membran kulit luar dan dalam disebabkan oleh perubahan suhu. Telur yang segar memiliki kantong udara yang lebih kecil dibandingkan telur yang sudah lama. Kantong udara dapat dijadikan sebagai petunjuk umur pada telur, makin besar kantong udara umur telur relatif makin lama (Muchtadi dan Sugiyono, 1992 dalam Refriyetni, 2011).

Menurut Jazil et al. (2013), kantong udara pada telur terbentuk sesaat setelah peneluran akibat adanya perbedaan suhu ruang yang lebih 
rendah dari suhu tubuh induk, kemudian isi telur menjadi lebih dingin dan mengkerut sehingga memisahkan membran kerabang bagian dalam dan luar, terpisahnya terjadi pada bagian tumpul telur. Semakin lama penyimpanan telur maka akan semakin besar kedalaman kantong udaranya. Peningkatan ukuran kantong udara disebabkan oleh penyusutan berat telur yang diakibatkan penguapan air dan pelepasan gas yang terjadi selama penyimpanan. Seiring bertambahnya umur, telur akan kehilangan cairan dan isinya semakin menyusut sehingga memperbesar rongga udara.

Terdapatnya perbedaan indeks albumin antara telur pasok dengan telur lokal diduga disebabkan oleh lama dan panjangnya proses distribusi pemasaran telur. Selain lamanya proses distribusi, faktor suhu dan $\mathrm{pH}$ juga merupakan salah satu penyebab penurunan kualitas albumin telur. Suhu dalam kontainer dapat meningkat (38-39 ${ }^{\circ} \mathrm{C}$ ) akibat kurangnya ventilasi untuk sirkulasi udara. Penyimpanan yang semakin lama dan suhu yang tinggi akan menyebabkan $\mathrm{pH}$ telur menjadi basa.

Menurut Argo et al. (2013), faktor-faktor yang mempengaruhi nilai indeks albumin antara lain lama penyimpanan, suhu tempat penyimpanan, dan nutrisi pakan. Kasmiati (2014) menyimpulkan bahwa rata-rata indeks albumin telur ayam ras yang berada di kios, supermarket, pasar dan agen memiliki kualitas yang kurang baik seiring dengan semakin lama masa simpan telur. Keluarnya air dari jala-jala ovomucin yang berfungsi sebagai pembentuk struktur albumin menjadi penyebab penurunan nilai indeks albumin sehingga semakin lama telur disimpan, indeks albuminnya semakin kecil (Rosidah, 2006).

Penurunan kualitas albumin menurut Cornelia et al. (2014), terjadi akibat adanya penguapan air dan gas seperti $\mathrm{CO}_{2}$ yang menyebabkan albumin kental menjadi semakin encer. Selanjutnya menurut Jazil (2013) mengemukakan bahwa kenaikan $\mathrm{pH}$ albumin menyebabkan kerusakan serabut-serabut ovomucin (yang memberikan tekstur kental) menyebabkan kekentalan albumin telur menurun.

Buckle et al. (2007), mengemukakan bahwa indeks albumin makin mengecil akibat degradasi ovomucin yang dipercepat dengan meningkatnya suhu dan $\mathrm{pH}$ telur. Sedangkan menurut Hiroko et al. (2014), penurunan kualitas pada albumin disebabkan oleh banyaknya pori-pori pada kerabang sebagai akibat dari rongga udara yang semakin membesar. Banyaknya pori-pori pada kerang telur menyebabkan penguapan $\mathrm{CO}_{2}$ dan $\mathrm{H}_{2} \mathrm{O}$ lebih banyak. Akibat adanya penguapan $\mathrm{CO}_{2}$, bagian kental albumin yang semula memanjang akan merenggang menjadi pendek dan menekan keluar albumin kental sehingga ovomucin pecah. Berkurangnya tinggi albumin akibat migrasi air dari albumin ke yolk menyebabkan interaksi antara lysozyme dengan ovomucin yang menyebabkan berkurangnya daya larut ovomucin dan merusak kekentalan albumin.

Hal tersebut dipertegas oleh pendapat Indratiningsih dan Rihastuti (1996) dalam Rahmawati et al. (2014), yang menyatakan bahwa penguapan air dan $\mathrm{CO}_{2}$ sangat berpengaruh pada derajat keasaman putih dan kuning telur ayam ras. Jika air dan $\mathrm{CO}_{2}$ dalam telur semakin berkurang, maka $\mathrm{pH}$ menjadi sangat basa sehingga akan menurunkan kualitas interior telur ayam ras tersebut yang berakibat pada terjadinya pembusukan telur.

Terjadinya perbedaan indeks yolk telur antara distributor, pengecer dan kontrol diduga disebabkan oleh suhu dan pengaruh lama penyimpanan telur. Peningkatan suhu menyebabkan penguapan air dan $\mathrm{CO}_{2}$ sehingga yolk telur ayam menjadi encer. Penurunan kualitas yolk telur juga dipengaruhi oleh lama penyimpanan, semakin lama penyimpanan menyebabkan membran viteline mudah pecah karena kehilangan kekuatan dan elastisitas sehingga indeks yolk menurun setelah disimpan selama beberapa minggu. Selain hal tersebut, adanya perpindahan air dari albumin ke yolk diduga turut menyebakan terjadinya pembesaran yolk sehingga menjadi lembek dan mudah pecah.

Menurut Buckle et al. (2007), indeks yolk yang rendah disebabkan oleh membran vitelin kuning telur tidak kuat karena air dari albumin telah memasuki yolk secara difusi sehingga terjadi pembesaran yolk dan yolk menjadi lembek. Selanjutnya menurut Hiroko et al. (2014), selama masa penyimpanan terjadi 
proses perpindahan air dari putih telur ke kuning telur disertai dengan peregangan dan pecahnya membran viteline. Hal ini menyebabkan pelebaran kuning telur sehingga menurunkan indeks kuning telur. Penurunan kualitas pada yolk mengindikasikan terjadinya kerusakan membran viteline yang berfungsi melindungi yolk. Semakin lama penyimpanan maka kandungan air pada albumin yang yang berada disekeliling yolk akan terserap ke dalam yolk yang menyebabkan berkurangnya permiabilitas membran viteline sehingga menyebabkan terjadinya percampuran albumin dan yolk. Penurunan indeks yolk merupakan fungsi dari kekuatan membran viteline. Semakin lama penyimpanan, membran viteline mudah pecah karena kehilangan kekuatan dan menurunnya elastisitas sehingga indeks yolk menurun setelah disimpan selama beberapa minggu.

Hal tersebut dipertegas oleh Sodak (2011) dalam Rahmawati et al. (2014), yang menyatakan bahwa yolk telur ayam ras akan semakin menurun selama penyimpanan akibat perusakan ovomucin. Penguapan air dan $\mathrm{CO}_{2}$ dapat menyebabkan yolk telur ayam ras menjadi encer sehingga nilai $\mathrm{pH}$ akan semakin basa. Semakin basa nilai $\mathrm{pH}$ yolk telur ayam ras, maka akan menurunkan kualitas interior dari telur ayam ras tersebut yang berakibat terjadinya pembusukan. Keadaan ini sejalan dengan hasil pengukuran kualitas telur berdasarkan indeks albumin.

\section{KESIMPULAN}

Berdasarkan kualitas fisik, lama penyimpanan dan rantai pemasaran, telur ayam ras pasok di Kabupaten Manokwari telah mengalami penurunan kualitas.

\section{DAFTAR PUSTAKA}

Argo L.B., Tristiarti dan Mangisah I. 2013. Kualitas fisik telur Ayam Arab fase I dengan berbagai level Azolla microphylla. Animal Agriculture Journal. 2(1):445-457.

Arizona R. dan Ollong A. R. 2020. Kualitas telur puyuh selama penyimpanan dan temperatur yang berbeda. Jurnal Ilmu Peternakan dan Veteriner Tropis 10 (1): 70-76.
Badan Pusat Statistik Kabupaten Manokwari. 2016. Kabupaten Manokwari dalam Angka 2016. https://manokwarikab.bps.go.id.

Buckle K. A., Edwards R. A., Fleedrds G. H., Wooton M. 2007. Ilmu Pangan. Terjemahan Hari Purnomo dan Adiono. UI Press. Jakarta.

Buckle K. A., Edwards R. A., Fleedrds G. H., Wooton M. 2009. Ilmu Pangan. Jakarta ID: Universitas Indonesia Press.

Cornelia A., Suada I. K. dan Rudyanto M. D. 2014. Perbedaan daya simpan telur ayam ras yang dicelupkan dan tanpa dicelupkan larutan kulit manggis. Indonesia Medicus Veterinus. 3(2):112-119.

Dinas Peternakan dan Kesehatan Hewan Provinsi Papua Barat. 2016. Buku Statistik Peternakan Provinsi Papua Barat Tahun 2012-2016. Dinas Peternakan dan Kesehatan Hewan Provinsi Papua Barat. Manokwari.

Hiroko S. P., Kurtini T. dan Riyanti. 2014. Pengaruh lama simpan dan warna kerabang telur ayam ras terhadap indeks albumen, indeks yolk, dan ph telur. Jurnal Ilmiah Peternakan Terpadu. 2(3): 108-114.

Idris M. 1994. Pembuatan Telur Asin Dengan Cara Penyuntikan. Majalah Poultry Indonesia No. 176. P: 18. Poultry Indonesia. Jakarta.

Jazil N, Hintono, dan Mulyani S. 2013. Penurunan kualitas ayam ras dengan intensitas warna coklat kerabang berbeda selama penyimpanan. Jurnal Aplikasi Teknologi Pangan. 2 (1): 43-47.

Kasmiati. 2014. Kualitas fisik telur konsumsi ayam ras yang beredar di Kota Manokwari. Skripsi. Fakultas Peternakan, Perikanan dan Ilmu Kelautan Universitas Negeri Papua, Manokwari.

Mountney G. J. 1981. Poultry Product Technology. Second Eddition. The Avi Publishing Company Inc. Westport Connecticut.

Rahmawati S., Setyawati T. R., dan Yanti A. H. 2014. Daya simpan dan kualitas telur ayam ras dilapisi minyak kelapa, kapur sirih dan ekstrak etanol Kelopak Rosella. Jurnal Protobiont. 3(1):55-60.

Refriyetni W. 2011. Mutu fisik telur ayam ras (studi kasus di pasar simpang baru) Kota Pekanbaru. Skripsi. Program Studi 
Peternakan Fakultas Pertanian dan Peternakan Universitas Islam Negeri Sultan Syarif Kasim Riau.

Rosidah. 2006. Hubungan umur simpan dengan penyusutan bobot, nilai haugh unit, daya simpan dan kestabilan buih putih telur itik tegal pada suhu ruang. Skripsi. Fakultas Peternakan. Institut Pertanian Bogor. Bogor.
Samli H. E., Agma A. and Senkoylu N. 2005. Effect of storage time and temperatur on egg quality in old laying hens. Journal of Applied Poultry Ressearch. 14 (1)):548553.

SNI 3926. 2008. Telur Ayam Konsumsi. ICS 67.120.20. Badan Standardisasi Nasional. Stasiun Karantina Pertanian Kelas II Manokwari. 2017. Data Pemasukan Bahan Pangan Asal Hewan. SKP, Manokwari. 